\title{
INCORPORATION IN THE FORM OF HORIZONTAL CONDOMINIUMS IN THE METROPOLITAN REGION OF FORTALEZA, BRAZIL
}

\author{
a incorporação sob a forma de condomínio horizontal \\ na Região Metropolitana de Fortaleza, Brasil
}

Francisco Clébio Rodrigues Lopes*

\begin{abstract}
Resumo
A partir de 1998 com a criação do Sistema Financeiro Imobiliário (SFI), o setor imobiliário brasileiro passou por mudanças estruturais. Dentre as principais está a forte capitalização das grandes incorporadoras mediante a abertura de capitais em bolsa de valores o que permitiu a expansão da incorporação imobiliária por todo território brasileiro. Regiões brasileiras que historicamente tiveram baixo preço do $\mathrm{m} 2$ e demanda solvável reduzida passaram a receber novos empreendimentos, até mesmo em áreas periféricas e carentes de infraestrutura, evidenciando uma suburbanização. Assim, a compreensão da urbanização enquanto economia política do espaço permite analisar a proximidade cada vez mais tênue entre espaço urbano e capital financeiro, bem como os fetiches envolvidos.
\end{abstract}

Palavras-chaves: Setor imobiliário; Urbanização; Economia política; Sociedade urbana

\begin{abstract}
With the creation of the Real Estate Financing System (SFI) in 1998, the real estate sector in Brazil underwent structural changes. Among the main ones is the strong capitalization of the big developers through the initial public offering on the stock market which allowed the expansion of the real estate development throughout Brazil. Brazilian regions that have historically had low price of land per $\mathrm{m} 2$ and reduced solvable demand started to receive new ventures, even in peripheral areas with deficient infrastructure, showing suburbanization. Thus, an understanding of urbanization as a political economy of space allows an analysis of the increasingly tenuous proximity between urban space and financial capital, as well as the fetishes involved.
\end{abstract}

Key words: Real estate sector; Urbanization; Political economy; Urban society.

\section{Resumen}

A partir de 1998 con la creación del Sistema Financeiro Imobiliário (SFI), el sector inmobiliário brasileño experimentó cambios estructurales. Entre los más importantes está la fuerte capitalización de los grandes desarolladores abriendo el capital en bolsa de valores que permitió la expansión de la incorporación en todo Brasil. Regiones del país que históricamente han tenido bajo precios del $\mathrm{m} 2$ y la reducción de la demanda resoluble comenzaron a recibir nuevas empresas, incluso en zonas periféricas con infraestructura deficiente, lo que evidencia una suburbanización. Por lo tanto, la comprensión de la urbanización como economía política del espacio nos permite analizar la cercanía cada vez más borrosa entre el espacio urbano y el capital financeiro, así como los fetiches involucrados.

Palabras clave:: Sector inmobiliário; Urbanización; Economía política; Sociedad urbana.

(*) Lecturer, Doctor of the State University of Matanhão (Universidade Estadual do Maranhão) - Cidade Universitária Paulo VI, Caixa Postal 09, São Luís (MA), Brasil. Fone: (+55 98) 3245-5461. clebiolopes@yahoo.com.br 


\section{INTRODUCTION}

In the last twenty years, there has been a growth in the construction of commercial (shopping malls, supermarkets and office towers) and residential (vertical and horizontal condominiums) surfaces in the southeast of the Metropolitan Region of Fortaleza (MRF), about $20 \mathrm{~km}$ from downtown, especially after the widening of the Washington Soares Avenue / CE 040 highway, which evidences a clear suburbanization. Property developers have called this area the "Agua Fria Region", that is, territorial portions of the municipalities of Fortaleza, Eusébio and Aquiraz, which do not observe political and administrative boundaries and forge their own regionalizations.

The fascination with life in a horizontal gated condominium lies with the construction of status symbols, whose "subjects" identify themselves by affirming social inequalities, so the purchase of the asset involves an acquisition of a reenactment of lived experience which allows this distinction. Thus, the economics happens through the creation of fetishes, including the suburban space. This article aims to understand spatial production as a business inside the circulation of capital interest, using a case study.

\section{REAL ESTATE AS A PRIVATE BRANCH OF CAPITAL INTEREST}

During the Ceremony to award the prize for "Real Estate Distinction" at the Caesar Park Hotel in Fortaleza in February 1998, Armando Cavalcante (treasurer of the Federal Council of Real Estate Agents and director of the Regional Council of Real Estate Agents of Ceará - CRECI) made some statements about the trends in real estate in the capital of the state of Ceará:

In less than two years, Fortaleza will experience a boom of $60 \%$ in the offer of properties located in horizontal condominiums.

[...] the middle class is fleeing to neighborhoods 16 to 25 kilometers from the downtown area, looking for space which many apartments do not offer, with the security of a gated condominium.

With the widening of the CE 040 highway (giving access to Aquiraz), large plots demonstrate to region's potential. I believe that the offer of this type of housing will grow at least $60 \%$ by December 1999. In Água Fria, the offer of properties has already grown around 30\%.

The new undertakings will bring new activities and services in their wake (banks, commerce), which will also make these regions attractive to vertical condominiums. According to the current Law on Land Use and Occupation of Fortaleza, these expansion zones are not permitted to have buildings with more than three floors, apart from the corridors of activities such as the Washington Soares avenue [...] (DIÁRIO DO NORDESTE, 1998).

In addition to the spectacular character of the journalistic material that focused on the awards presented by the CRECI, its content is revealing. Firstly, it was one year since Law 9514 had been enacted, creating the Real Estate Financing System - SFI, whose objective was to bring together the mortgage and the capital markets by creating instruments that guarantee security to investors. That same year, the "New Washington Soares Avenue" was inaugurated and like sunshine after months of winter, this inauguration raised many lots from the lethargy in which they found themselves.

In the case of Fortaleza, the creation of the SFI and the IPO on the stock exchange from 2004 by the large property developers strengthened the incorporation by the insertion of new companies from the Rio-São Paulo axis, the restructuring of local traditional companies and the emergence of new groups. Floating a new issue on the capital markets allowed the national firms to amplify their investment throughout the Brazilian territory, especially the Northeast, which historically had a repressed demand and low-priced urban land (Table 1). The mechanism used by national legal entities to penetrate a resistant market like Fortaleza was to form partnerships (legally these were 
Special Purpose Entities - SPE) with real estate establishments from Ceará state; however, this had implications for the organization of the work. Whilst the national groups focused on the real estate business, overseeing the production and marketing of enterprises, the local companies were responsible for the construction itself (RUFINO, 2012).

The arrival of the large property developers (Gafisa, MRV, Cyrela and Rossi) resulted in a greater intensification of land purchases in Fortaleza since the securities issued on the stock exchange are valued in accordance with the expectation of growth, measured by the general sales value (PSV) of the developers. Hence the strategy of land banking, because the soil serves as a ballast to enable future production, consequently, there was an increase in prices (Table 2). On the other hand, state action reducing the interest rate, extending the terms of financing, rising wages and lower inflation have created an artificial demand, supported by the state government's debt. However, the basic price of the land is not derived simply from supply and demand, but represents a sum of interest rates, capital amortization used in the city's production plus the payment of capitalized income (PEREIRA, 1988).

With the increase in the price of lots, the way the construction companies found to reduce spending was to dilute land costs by concentrating a large number of units, guaranteeing a greater rationalization and standardization of construction so that production takes less work time. The real estate product in the form of the condominium simultaneously allowed a reduction in the cost of the work and an increase in the price of the units as this merchandise includes facilities for common use. In this way, supported by programs such as Minha Casa, Minha Vida - MCMV (My House, My Life), it was possible to generalize this product in the metropolitan periphery of Fortaleza as it was possible to reach non-solovable demand.

\section{ÁGUA FRIA REGION: INCORPORATION IN THE FORM OF HORIZONTAL CONDOMINIUMS}

Living in condominiums reproduces itself through the fetish of restrictive acquisition, which differentiates its residents from the rest of the city, as co-ownership ensures the exclusive use of leisure areas, facilities and services. In addition, the presence of these objects creates a false illusion of a superior daily life, far from the problems of the urban centers, therefore allowing the integration of formerly restricted spaces with precarious conditions of urbanization into the real estate expansion. The incorporation of new niches by creating values of use for the house-as-merchandise (differentiation of the project itself and / or the appropriation of space) influences the growth in the amount of money paid for this spatiality.

In this context of inducing differences as a strategy of incorporation, the "Água Fria Region" emerges as a space for the valorization of financial capital in RMF. From a space characterized by smallholdings, housing estates and favelas, it became a private suburb for the middle class. Rapidly, the lots became the most expensive on the market (TABLE 2), close to the Washington Soares Avenue horizontal condominiums were built from the 1990s onwards (the pioneer was Royal Park with 44 houses, in 1996).

Horizontal condominiums have between 20 and 50 houses, offering the residents leisure facilities and security devices. The houses are between 100 and $300 \mathrm{~m} 2$, with up to five bedrooms with en suite bathrooms, two stories and garage space for more than one car and cost between R\$ 130,000 and R\$ 700,000 (TABLE 3). These high-end undertakings, intended for the middle classes, are located in an area that does not have a sewage network, hence the security accessories and equipment to attract consumers.

In the research we carried out on the construction companies' sites, we were able to map around 50 horizontal condominiums and 17 construction companies with undertakings scattered in the neighborhoods of Edson Queiroz, Sapiranga, José de Alencar, Curió and Lagoa Redonda, all located on the eastern margin of the Washington Soares, whilst on the western margin there is 
LOPES, F. C. R.

Table 1 - Price of the $\mathrm{m}^{2}$ in Brazil in 2010

\begin{tabular}{|c|c|c|c|c|}
\hline \multirow{2}{*}{ Geographical areas } & \multirow{2}{*}{$\begin{array}{c}\text { Average costs } \\
\mathrm{R} \$ / \mathrm{m}^{2}\end{array}$} & \multicolumn{3}{|c|}{ Percentage variation } \\
\hline & & Monthly & In the year & 12 months (accumulated) \\
\hline Brazil & 747,36 & 0,66 & 4,33 & 6,52 \\
\hline North & 747,18 & 0,44 & 4,42 & 8,14 \\
\hline Northeast & 702 & 0,75 & 4,58 & 7,02 \\
\hline Southeast & 792,23 & 0,59 & 4,4 & 6,15 \\
\hline South & 724,26 & 0,93 & 3,1 & 5,43 \\
\hline Centre-West & 720,5 & 0,54 & 5,23 & 7,1 \\
\hline
\end{tabular}

Source - IBGE/Caixa Econômica, 2010.

Organized by Francisco Clébio Rodrigues Lopes.

Table 2 - Price of the $\mathrm{m}^{2}$ in neighborhoods in the Metropolitan Region of Fortaleza (MRF) between 2005/2006 and 2010/2011

\begin{tabular}{|c|c|c|c|c|c|c|}
\hline \multirow{2}{*}{ Neighborhood } & \multicolumn{2}{|c|}{$2005 / 2006$} & \multicolumn{2}{|c|}{ 2010/2011 } & \multicolumn{2}{|c|}{$\%$ Growth - 5 years } \\
\hline & Minimum (R\$) & Maximum (R\$) & Minimum (R\$) & Maximum (R\$) & Minimum & Maximum \\
\hline Aldeota & 400 & 700 & 1.200 & 2.000 & 200 & 186 \\
\hline Cambeba & 30 & 70 & 350 & 700 & 1.067 & 900 \\
\hline Centro & 800 & 1.500 & 2.000 & 3.000 & 150 & 100 \\
\hline Cidade dos Funcionários & 100 & 180 & 700 & 2.000 & 600 & 1.011 \\
\hline Coaçu & 25 & 40 & 150 & 400 & 500 & 900 \\
\hline Curió & 25 & 40 & 300 & 400 & 1.100 & 900 \\
\hline Edson Queiroz & 180 & 240 & 1.000 & 3.500 & 456 & 1.358 \\
\hline Eusébio (locations close to the CE 040) & 30 & 50 & 150 & 200 & 400 & 300 \\
\hline Guajeru & 25 & 40 & 150 & 400 & 500 & 900 \\
\hline Guararapes & 100 & 150 & 1.500 & 3.500 & 1.400 & 2.233 \\
\hline Jardim das Oliveiras & 40 & 70 & 400 & 500 & 900 & 614 \\
\hline José de Alencar & 10 & 20 & 100 & 150 & 900 & 650 \\
\hline Luciano Cavalcante & 50 & 80 & 500 & 700 & 900 & 775 \\
\hline Lagoa Redonda & 8 & 12 & 200 & 350 & 2.400 & 2.817 \\
\hline Meireles & 600 & 4.000 & 3.000 & 12.000 & 400 & 200 \\
\hline Parque Iracema & 30 & 70 & 200 & 300 & 567 & 329 \\
\hline Parque Manibura & 15 & 25 & 100 & 200 & 567 & 700 \\
\hline Porto das Dunas & 20 & 35 & 100 & 150 & 400 & 329 \\
\hline Sabiaguaba & 10 & 20 & 80 & 150 & 700 & 650 \\
\hline Salinas & 10 & 15 & 150 & 250 & 1.400 & 1.567 \\
\hline
\end{tabular}

Organized by Francisco Clébio Rodrigues Lopes. 
a concentration of vertical condominiums. However, as they have very similar characteristics, we opted to include fourteen of them and six construction companies (Cadre 1).

A good example is Carneiro de Melo's Carmel Garden Condominium, launched in 2006. Each house was sold for R $\$ 400$ thousand, they have with a private area of $271 \mathrm{~m} 2$, five bedrooms with en suite (three have a walk-in wardrobe), garage space for up to six cars, maid's room, cable TV and internet connections. The condominium has 21 houses, a sentry-box, electric fence, automatic gate and internal communication system, swimming pool, a seven-a-side football pitch, running track, a party room and small squares. One noteworthy detail is the number of bedrooms and garage spaces, as in the conception of this space is an explicit deep desire for isolation that is not limited to the city; it extends into the homes. We are living in the era of the personal, all the consumer goods are now for individual use; this includes the computer, the car, the bathroom, the telephone, sound equipment, security and nature. Security devices also draws our attention, proving that, in a society of amplified survival (in the words of the Situationists), those who have private property (in the widest sense - from the means of production to the most simple consumer objects) live in fear of those who have been dispossessed of the most basic means of survival.

Cadre 1 - Horizontal condominiums in the "Água Fria Region” - 2010

\begin{tabular}{|c|c|c|c|c|c|c|c|}
\hline Undertaking & Launch & Location & $\begin{array}{l}\text { Built area of } \\
\text { the property } \\
\qquad\left(\mathrm{m}^{2}\right)\end{array}$ & $\begin{array}{l}\text { Total } \\
\text { units }\end{array}$ & $\begin{array}{l}\text { Number } \\
\text { of stories }\end{array}$ & $\begin{array}{l}\text { Construction com- } \\
\text { pany }\end{array}$ & $\begin{array}{l}\text { Average } \\
\text { price of } \\
\text { property } \\
(\mathrm{R} \$)\end{array}$ \\
\hline Carmel Park & 2004 & Cidade dos Funcionários & 185,48 & 32 & 2 & Carneiro de Melo & 264.000 \\
\hline Villa Carmel & 2005 & Sapiranga & 154,51 & 41 & 2 & Carneiro de Melo & 185.000 \\
\hline \multirow{2}{*}{$\begin{array}{l}\text { Monte Carmel } \\
\text { Village }\end{array}$} & \multirow{2}{*}{2005} & \multirow{2}{*}{ José de Alencar } & A: 237,68 & \multirow{2}{*}{23} & \multirow{2}{*}{2} & \multirow{2}{*}{ Carneiro de Melo } & 334.000 \\
\hline & & & B: 272,37 & & & & 354.000 \\
\hline Carmel Garden & 2006 & Cambeba & 271 & 21 & 2 & Carneiro de Melo & 395.000 \\
\hline Gran Carmel & 2007 & Sapiranga & 290 & 25 & 2 & Carneiro de Melo & 550.000 \\
\hline \multirow{2}{*}{ Carmel Jardins } & \multirow{2}{*}{2010} & \multirow{2}{*}{ Sapiranga } & A: 250 & \multirow{2}{*}{27} & \multirow{2}{*}{2} & \multirow{2}{*}{ Carneiro de Melo } & A: 670.000 \\
\hline & & & B: 230 & & & & B: 535.000 \\
\hline Laguna Ville & 2009 & Lagoa Redonda & 166,67 & 27 & 2 & Suporte & 550.000 \\
\hline Sun Ville & 2010 & Lagoa Redonda & 158,97 & 25 & 2 & Suporte & 309.000 \\
\hline Isola di Murano & 2006 & Edson Queiroz & 160 & 20 & 2 & $\begin{array}{l}\text { J Brasil Construções e } \\
\text { Empreendimentos }\end{array}$ & 350.000 \\
\hline Riviera de Capri & 2008 & Curió & 110 & 26 & 2 & $\begin{array}{l}\text { J Brasil Construções e } \\
\text { Empreendimentos }\end{array}$ & 135.000 \\
\hline Green Village & 2009 & Lagoa Redonda & 81,50 & 20 & 1 & Teixeira Oliveira & 190.000 \\
\hline Oliver Boulevard & 2009 & José de Alencar & 186,57 & 52 & 2 & Teixeira Oliveira & 435.000 \\
\hline Ásia Imperial & 2009 & José de Alencar & 177 & 14 & 2 & Morefácil & 390.000 \\
\hline Vila Safira & 2007 & Edson Queiroz & 118,01 & 06 & 2 & Cameron & 430.000 \\
\hline
\end{tabular}

Source: Direct Research, 2010.

Organized by Francisco Clébio Rodrigues Lopes.

The construction companies and developers mapped are Carneiro de Melo, Suporte, J Brasil Construções Empreendimentos, Teixeira Oliveira, Morefácil and Cameron - all of which have their head office in the city of Fortaleza. The first four specialize in building horizontal condominiums and the last two also produce vertical condominiums. 
Carneiro de Melo has operated since 2000, but it is part of a group that has been active for forty years in the fields of hotel management, food, representations and trade, and construction in Fortaleza (CE), Mossoró (RN) and Recife (PE). There are five siblings, each responsible for one company. The construction company is the responsibility of civil engineer Fábio Carneiro de Melo; Magna Locações has branches in Mossoró and Recife and offers construction support (rental of scaffolding, chemical toilets, containers and elevators) and together with Magna Metalúrgica it is administered by the civil engineer, Vitor; the hotels Magna Praia (Fortaleza) and Água Marinha (Fortaleza) as well as Carmel Charme Resort (Aquiraz - RMF) are in the care of Tarso; Carlos Valen directs the designer shoe shop; and Lina supports the whole group.

Suporte was founded in 2000 and only operates in the capital of Ceará, despite the partners being from Mossoró. After the merger with Boa Terra Construtora, it is administrated by Pedro Lasake (administrator), Otto Barreto (businessman) and Régis (civil engineer). So, like Carneiro de Melo, the group appears to have a family-based structure: “[...] Dr. Pedro is just auxiliary; he was not directly linked to the company. He was married to one of the partner's daughter when Suporte started up. They ended up separating, but because he's a good professional and so on [...] let Pedro stay there, even if he has split up with my daughter." (CONSTRUTORA SUPORTE, 2011).

Teixeira de Oliveira, established in 1999, is run by civil engineer Bruno Teixeira de Oliveira who is also an owner. The construction company has projects in Fortaleza and São Luís (MA), however the incorporation in Maranhão occurred through the opening of an SPE to build a horizontal condominium, without a partnership with the local group.

The rest are no more than 15 years old and have business in the MRF, the northern zone of Ceará (Sobral) and Rio Grande do Norte.

The developers, in general, are local and seem to operate with their own capital. As they are family groups, we had the impression that the closest things were resolved first and that the distant ones were fluid because during the interviews the answers about the financing of projects were vague. Thus, the responses to our questions brought more doubts than clarification because this type of product does not fit the profile of cost price production, where a group of interested parties join together and start work with the capital collected. This is pure real estate development and in some cases, the objects are defined as luxury, designer goods.

Carneiro de Melo has even launched more than one project per year and due to the price of each property, even with financing of a maximum of five years, the company would not have capital in the form of money for a new investment. However, this developer has a different profile from the others we interviewed (Suporte and Teixeira de Oliveira), as the accumulation does not depend just on one sector; there is composition of capital due to being part of a group.

[...] everything we have is our own resources. It's because it's a strong group and well consolidated, you see. So when we start a project, we already have all the funds for that project. We don't wait for the money from the sale to conclude. In fact, the last project we handed over like this was in Maraponga. We hardly received anything; see, because we receive after it is ready, because the financing is the biggest part, the biggest installment. Usually, until the keys are handed over, we receive $40 \%$ of the value of the property, the other $60 \%$ is only when it's ready (CONSTRUTORA CARNEIRO DE MELO, 2012).

When we inquired about the formation of partnerships as a capitalization mechanism we were told:

We only have, in fact, one partnership and that was a test, [...] It was a friend of his, who is an engineer, it is the Axix Engenharia construction company. It's a friend of his, [...] a friend of the family, Antônio Coelho, his friend. He took care of the construction, the whole part at the site. Fábio didn't worry about 
anything. The engineer responsible was Coelho and the administrative part was all done here at Carneiro de Melo. Paying bills, receiving bills and sales. And the costs were half and half, 50\% for Carneiro de Melo and 50\% for Carmel Axis (CONSTRUTORA CARNEIRO DE MELO, 2012).

This presence was also observed at Teixeira de Melo:

In my construction company, specifically here, for some projects, we have a company from Rio. They are a partner of ours, some cousins of mine, they are investors. So, they come in with a part of the funds, but not in all. They are just developers. Depending on the project and the opportunity, they can come in with us or not, with the money (CONSTRUTORA TEIXEIRA DE MELO, 2012).

We have already related the difficulty in detecting this wider circuit of financialization via real estate because everything appeared to be resolved by local accumulation, as the interviewees emphasized that the production relied on their own resources and therefore the connections with the national developers in this real estate sector (condominium of houses) did not occur. However, the difficulty in finding these links was precisely due to the plasticity of the business as the connection takes place through a temporary partnership. Legally, this is regulated by Law 11.079/2004 that ensures that this type of association is a SPE, a company created at the moment the land is acquired and dissolved once the keys have been handed over. Its intention is to deal with a single project without any contamination from other activities. This isolation of assets within an organization is guaranteed by the Segregation of Patrimony Institute (Law 10.931 / 2004), i.e., the assets of an enterprise are segregated from any others, including the bookkeeping.

We observed a passage within the division of labor, that is, a separation between the developer (perceived as the investor) and the constructor, so that the former takes care of accounts payable, accounts receivable and sales (Carneiro de Melo) and the latter does the construction work (Axis Engenharia). In this sense, Carneiro de Melo is still the construction company and developer, although it has already tested pure development once. Whereas with the intention of boosting its transactions, Teixeira de Melo sought out the investor OLSIX, which would act solely as the developer, only providing the money.

Another cloudy point was the relationship between the mortgage and capital markets, as the companies said they did not use modern sources of capitalization (IPO on the stock exchange and securitization instruments) and only Suporte said it used resources from the Caixa Economica Federal bank (CEF) to finance its projects.

This one here is basically our own resources, but the other one... Then they filed a suit at the Caixa to get the resources to finish, but until today [...] The other one is going to start [...] they are doing the inverse process, they have already handed in all the paperwork. Its fifteen days since we settled the amount to start the process at the Caixa, OK? It will work like this: as the project is built the Caixa goes to the site and makes measurements and makes the payment. That's how it is if I am building with the Caixa. This project here, (showing the plans for a future condominium) we are going to try and do that, right? Here the Caixa will monitor, it will work like a public bidding [...] the money is released according to the execution of the work (CONSTRUTORA SUPORTE, 2011).

Teixeira de Oliveira also cited the difficulty in using state credit, as the money is only released at the end of the works, due to the bureaucracy. In addition to their own resources, Suporte only mentioned the federal bank, as they had adopted a strategy for dealing better with the delay in the release of the money. The merchandise-dwelling has a long circulation period, that is, the return of the capital in monetary form and consequently the production of surplus value tend to be lengthy, so the need for credit is inevitable. 
The execution of large-scale works that require a significantly long period only passes through the capitalist production when the concentration of capital is already very significant, and, on the other hand, when the development of the credit system offers the capitalist the convenient recourse of advancing and thus risking other people's capital instead of their own. [...] As credit mediates, accelerates and increases the concentration of capital into one hand, it helps to shorten the work period and, therefore, the rotation time (MARX, 1984, p. 175).

In recent years, the State has taken on the role of the main inducer of Brazilian real estate production because in 2009 alone the CEF provided R 33 billion in credit for builders across the country. In June 2012, the federal bank reduced interest rates for legal entities to finance residential units, which fell from $11.5 \%$ to $10.3 \%$ in the Construction Company Plan program and could drop to $9 \%$ for customers of the bank. The payment term of the loan was extended from 24 months to 36 .

The Caixa Econômica is the predominant form of payment used by customers. Despite Carneiro de Melo stating on its website that has its own system of financing, that is, real estate is purchased in up to 60 months with a down payment of $10 \%$ of the property price, it was reported to us that $90 \%$ of their buyers use the CEF. Suporte discloses online that it offers financing through Bradesco Bank in up to 360 months, subject to a $40 \%$ down payment, however we were told that the Caixa Econômica also dominates the interventions.

How does it work? The company asks for a down payment, a guarantee. As far as I know, it's about $\mathrm{R} \$ 25$ thousand. You can give about 17, 15 and pay the other 10 thousand in one or two installments. Then, you go there. It's discussed between the client and the construction company [...] And the rest is financing from the Caixa. So what's the financing from the Caixa like? It's going to depend on your income [...] To receive the property, then you have to give the bank a deposit (CONSTRUTORA SUPORTE, 2011).

In June 2012, the CEF extended the repayment period of housing loans using savings deposits from 30 to 35 years and announced the reduction of the Housing Financing System - SFH interest rates from $9 \%$ p.a. to $8.85 \%$ p.a., which could reach $7.8 \%$ p.a. depending on the form of the client's relationship with the bank. For loans outside the SFH, interest rates fell from 10\% p.a. to $9.9 \%$ p.a., explaining its strong presence in transactions with the developers. We know about this federal bank's relationship with the capital market (LOPES, 2012), so in Fortaleza the incorporation feeds a global accumulation.

From the example of Carneiro de Melo, it is evident that the activity of incorporation is not limited to the purchase of land, construction and commercialization, because it also involves financing; then real estate acts as a private branch of the circulation of capital interest.

Ninety-five percent of the residents of these undertakings already lived in the city of Fortaleza and had an average family income of R \$ 7,000.00, according to J Brasil Construções e Empreendimentos. Those who had acquired a "Carmel" (a house in a luxury condominium by Carneiro de Melo) usually work for PETROBRÁS or are businesspeople and doctors who lived in apartments in the Aldeota neighborhood, using these properties as a down payment. Both in Carneiro de Melo and at Suporte many clients had family or friendship links prior to moving to the horizontal condominium. The desire to belong to an isolated closed community, if possible from the same family group, in which you can enjoy exclusive facilities and services, and above all live among equals, seems to be the main motivation of the residents. 
There have been families who bought three houses. The father and two sons, it's quite common here. One of our condominiums had a family who bought into the condominium and their other neighbors all bought houses. Four people bought one, who used to be neighbors in the same condominium. They all bought one so they could be neighbors in our company's condominium. (CONSTRUTORA CARNEIRO DE MELO, 2012).

To make this type of project viable the most onerous aspect is buying the land itself because it is necessary to buy a plot with a minimum of seven thousand square meters. In the last five years there has been a substantial increase in the value of land (TABLE 2) due to the strong competition among developers to accumulate land banks in that area. Furthermore, the installation of the first condominiums, even in areas with a precarious infrastructure has made land more expensive.

Nowadays, the first difficulty is finding the land [...] due to the price and because there aren't that many plots and the ones there are, the owners are asking for a high price [...] So, it's hard today to get a plot, because the big developers have gone to the region: Marquise, MRV, Dias de Sousa and some from outside. They inflate the prices a lot, because they go after it, they offer an exchange to the owners, they say they are going to pay $x$ but it's in real estate (CONSTRUTORA TEIXEIRA DE OLIVEIRA, 2012).

This new project, in reality, where I'm starting it, there used to be a school called Irmã Maria Montenegro $[\ldots]$, it isn't the school, it was [...] the leisure area, the holiday club. It is in Guajeru, near the Naturágua plant [...] In that section, where Suporte works, they have done some projects out that way. There are a lot of plots of land in that section, blocks that belong just to one person. To give you an example: our block is where the school holiday club was, in the same block its Chico do Caraguejo, right? In front are the people from M Dias Branco, [...], on the other block there's another condominium [...] Suporte is focusing on residences and in this area because there is a lot of land [...] Around this project, I went to two places with big lots, which are intended for new projects (CONSTRUTORA SUPORTE, 2011).

The "Água Fria Region” is considered an area of expansion for Aldeota, a space where the city's bourgeoisie have historically located themselves. The fact that property was pulverized in the 1950s and 1960s and the lack of infrastructure kept the price of the $\mathrm{m} 2$ low, however, the boom that began in mid-1990s already shows signs of dwindling. According to André Montenegro, vice president of SINDUSCON / CE (Association of Civil Construction of Ceará), the main reason for the construction of condominiums in the metropolitan municipalities is the lack of cheap land in the capital. He gives Água Fria as an example, as it led the expansion of the eastern area and nowadays has almost no sizeable areas for horizontal condominiums.

The gated communities are found in the metropolitan municipalities; the largest are: AlphaVille Fortaleza, AlphaVille Eusébio and Quintas do Lago Fortaleza. AlphaVille Fortaleza, located in Aquiraz (MRF), was launched by a company from São Paulo, AlphaVille Urbanismo S/A, in 2003. It has an area of 1,188,200 $\mathrm{m} 2$ divided into residential $(425,149.40 \mathrm{~m} 2)$, commercial $(43,461.89 \mathrm{~m} 2)$, green $(475,663.43 \mathrm{~m} 2)$ and public $(380,101.76 \mathrm{~m} 2) ; 770$ residential and 27 commercial lots were sold in 80 days to a local demand. AlphaVille Eusébio is located in the metropolitan municipality of Eusébio and was launched in 2005. It has an area of 534,313.82 $\mathrm{m} 2$ distributed into residential $(238,928.05 \mathrm{~m} 2)$, commercial $(8,235.65 \mathrm{~m} 2)$, green $(164,828.17 \mathrm{~m} 2)$ and public $(258,964.18 \mathrm{~m} 2)$; 497 residential lots and 7 commercial were offered for sale. The lots in AlphaVille were commercialized by the company CIA Lançamentos Imobiliarios from São Paulo.

Quintas do Lago was inaugurated by Ceará's Terra Brasilis group in 2005 with an area of $323,336.72 \mathrm{~m} 2$ prorated into residential $(158,751.03 \mathrm{~m} 2)$, commercial $(7,318.27 \mathrm{~m} 2)$ and public 
(59,168.67 m2). 283 lots were put on the market, their size was between $500 \mathrm{~m} 2$ and 1,600 $\mathrm{m} 2$ and the cost was around R $\$ 75$ thousand; after a year their value was estimated at R $\$ 120$ thousand. All the lots were sold in four months, representing an overall volume of sales of R $\$ 32$ million. The construction company Guia, from Ceará, received 60 lots from owners as credit to buy the houses readymade, each house is $250 \mathrm{~m} 2$ and they were sold for $\mathrm{R} \$ 280,000$. According to Guia, $50 \%$ of purchasers are southerners, but already living in Fortaleza.

Terra Brasilis has projects in Ceará, Rio Grande do Norte and Alagoas and has partnerships with the builders and developers TECNISA and TATI from São Paulo and the English group Key Worth. In 2003, it launched the Loteamento Vila Verde; sales were done through Escala Construções Imobiliárias and 349 lots were sold in three months. In 2006, the Jardins da Serra in Maracanaú (MRF) with 2,600 lots was presented, but only the first stage was delivered, that is, Jardins de Baturité e Guaramiranga, the Jardims de Maranguape e Pacatuba are being developed.

\section{FINAL CONSIDERATIONS}

The reinvention of the use of the house-as-merchandise as a capitalization strategy directed the incorporation to the southeast of Fortaleza and the municipalities of the MRF, however, due to the difficulties of reproduction, growth took place through the articulation of multiple scales. In this sense, the production of space became autonomous from the administrative and political territory and takes place in networks as a result of the articulations performed by capital, yet the state still plays a key role, whether providing credit, regulating commercial transactions, implementing infrastructure or mediating conflicts. Although the development of real estate targets the interest on the capital invested in land, it is still presented as the creation of dwelling places, which has implications for the lived experience. The creation of a lifestyle that has as its main feature the segregation of the wealthy classes in an area historically occupied by the proletariat has strong daily consequences, as the places are only juxtaposed on the urban fabric.

\section{BIBLIOGRAPHIC REFERENCE}

Construção civil. CE tem o segundo $\mathrm{m}^{2}$ mais caro do Nordeste. Diário do Nordeste, Fortaleza, 08 de julho de 2010, Negócios. Disponível em: <http://diariodonordeste.globo.com/>. Acesso: 08 jul. 2010.

LOPES, F. C. R. Fortaleza vai continuar andando para o leste: suburbanização, ideologia e cotidiano. 2012. 317 f. Tese (Doutorado em Geografia Humana) - Faculdade de Filosofia, Letras e Ciências Humanas, Universidade de São Paulo, São Paulo, 2012.

Mais crédito. Construção terá R \$ 3 bi do FGTS. Diário do Nordeste, Fortaleza, 05 de setembro de 2009, Negócios. Disponível em: <http://diariodonordeste.globo.com/>. Acesso: 05 de set. 2009.

Mais mudanças. Financiamento do imóvel vai a 35 anos na Caixa; juro baixa. Diário do Nordeste, Fortaleza, 06 de junho de 2012. Disponível em: <http://diariodonordeste.globo.com/>. Acesso: 06 de jun. 2012. MARX, K. O capital: crítica da economia política. Livro II. São Paulo: Abril Cultural, Coleção "Os Economistas", 1984.

Oferta de condomínios horizontais deve crescer. Diário do Nordeste, Fortaleza, 02 de outubro de 1998, Fortaleza.

PEREIRA, P. C. X. Espaço, técnica e construção: o desenvolvimento das técnicas construtivas e a urbanização do morar em São Paulo. São Paulo: Nobel, 1988.

RUFINO, M. B. C. Incorporação da metrópole: centralização do capital no imobiliário e nova produção do espaço em Fortaleza. 2012.332 f. Tese (Doutorado em Arquitetura e Urbanismo) - Faculdade de Arquitetura e Urbanismo, Universidade de São Paulo, São Paulo, 2012. 
Terrenos escassos na capital. Condomínios ganham a RMF. Diário do Nordeste, Fortaleza, 14 de abril 2009, Cidade. Disponível em: <http://diariodonordeste.globo.com/>. Acesso: 14 maio 2009.

Submitted january 2016

Accepted february 2016 